\title{
134. Studies on Inflammability of Hydrogen.
}

IX. The Inflammability of Hydrogen-Nitrogen Mixtures and Hydrogen-Carbon Dioxide Mixtures and the Effect of Explosion-Suppressors Thereupon.

By Yoshio Tanaka and Yûzaburô NagaI. Aeronautical Research Institute, Tokyo Imperial University.

(Rec. Oct. 7, 1929. Comm. by K. Tawara, Nov. 13, 1929.)

The authors studied the limits of inflammability of Hydrogennitrogen mixtures and hydrogen-carbon dioxide mixtures. The effects of tetramethyl tin on the limits of the above mixtures were also studied in order to find out the lowest possible concentration of nitrogen or carbon dioxide, to make the mixtures incombustible, in the simultaneous presence of the tin compound. All limits were determined in a glass tube of $5 \mathrm{~cm}$. in diameter and $65 \mathrm{~cm}$. long, in which gaseous mixtures were ignited from the top by the electric spark, both ends of the tube being kept closed when the spark was passed.

The results are shown in the following tables:

Table I. Limits of inflammability of hydrogen-nitrogen mixtures in air.

\begin{tabular}{c|c|c}
\hline $\begin{array}{c}\text { Mol } \% \text { of } \mathrm{N}_{2} \\
\text { in limit }\end{array}$ & \multicolumn{2}{|c}{$\begin{array}{c}\text { Mol } \% \text { of } \mathrm{H}_{2} \text { in limit } \\
\text { mixtures. }\end{array}$} \\
mixtures.1) & Lower limit. & Upper limit. \\
\hline 0 & 8.8 & 71 \\
20 & - & 55 \\
30 & - & 45 \\
45 & - & 33 \\
50 & 9 & - \\
55 & - & 23 \\
60 & 10 & - \\
62 & - & 17 \\
\hline
\end{tabular}

Table II. Effect of tetramethyl tin on the limits of inflammability of hydrogen-nitrogen mixtures.

\begin{tabular}{|c|c|c|c|}
\hline \multicolumn{2}{|c|}{$\begin{array}{c}\text { Mol of } \mathrm{Sn}\left(\mathrm{CH}_{3}\right)_{4} \\
\text { and } \mathrm{N}_{2} \text { in } \\
\text { limit mixtures. }\end{array}$} & \multicolumn{2}{|c|}{$\begin{array}{l}\text { Mol } \% \text { of } \mathrm{H}_{2} \text { in } \\
\text { limit mixtures. }\end{array}$} \\
\hline $\mathrm{Sn}\left(\mathrm{CH}_{3}\right)_{4}$ & $\mathrm{~N}_{2}$ & $\begin{array}{l}\text { Lower } \\
\text { limit. }\end{array}$ & $\begin{array}{l}\text { Upper } \\
\text { limit. }\end{array}$ \\
\hline 0.50 & 0 & 9.5 & 49 \\
\hline 0.50 & 10 & - & 35 \\
\hline 0.50 & 20 & 10 & 23 \\
\hline 0.50 & 25 & - & $\begin{array}{l}\text { Not inflam- } \\
\text { mable in } \\
11 \% \text { and } \\
14 \% \text { of } \mathrm{H}_{2} .\end{array}$ \\
\hline 0.75 & 20 & 12 & 17 \\
\hline 1.00 & 20 & 12 & - \\
\hline
\end{tabular}

1) The figures in this column refer only to the amount of pure nitrogen added and so the nitrogen contained in air is not counted in these figures. 
Table III. Limits of inflammability of hydrogen-carbon dioxide mixtures in air.

\begin{tabular}{|c|c|c|}
\hline \multirow{2}{*}{$\begin{array}{l}\mathrm{Mol} 0_{0}^{\circ} \text { of } \\
\mathrm{CO}_{2} \text { in limit } \\
\text { ixtures. }\end{array}$} & \multicolumn{2}{|c|}{$\begin{array}{l}\text { Mol } \% \text { of } \mathrm{H}_{2} \text { in limit } \\
\text { mixtures. }\end{array}$} \\
\hline & Lower limit. & Upper limit. \\
\hline 0 & 8.8 & 71 \\
\hline 10 & - & 60 \\
\hline 20 & - & 49 \\
\hline 30 & - & 37 \\
\hline 40 & 11 & 26 \\
\hline 50 & - & $\begin{array}{l}\text { Not inflammable } \\
\text { in } 12 \%, 13 \% \text { and } \\
15 \% \text { of } \mathrm{H}_{2} \text { and }\end{array}$ \\
\hline
\end{tabular}

Fig. I.

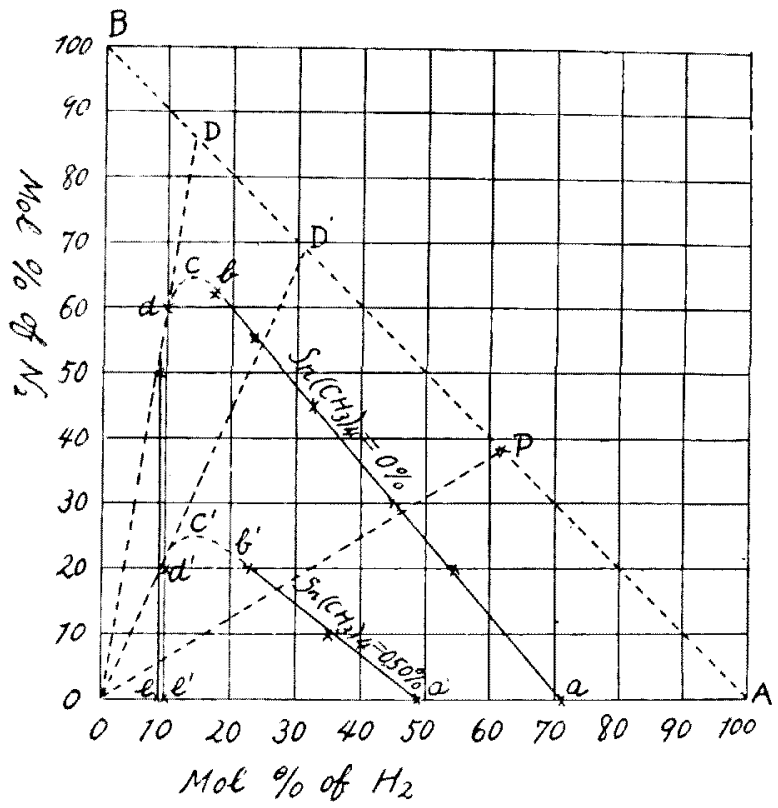

Table IV. Effect of tetramethyl tin on the limits of inflammability of hydrogen-carbon dioxide mixtures.

\begin{tabular}{c|c}
\hline $\mathrm{Mol} \%$ of $\mathrm{Sn}\left(\mathrm{CH}_{3}\right)_{4}$ & Mol $\because \%$ of $\mathrm{H}_{2}$ in \\
and $\mathrm{CO}_{2}$ in & limit mixtures. \\
limit mixtures. &
\end{tabular}

\begin{tabular}{|c|c|c|c|}
\hline $\mathrm{Sn}\left(\mathrm{CH}_{3}\right)_{4}$ & $\mathrm{CO} z$ & $\begin{array}{l}\text { Lower } \\
\text { limit. }\end{array}$ & $\begin{array}{l}\text { Upper } \\
\text { limit. }\end{array}$ \\
\hline 0.50 & 0 & 9.5 & 49 \\
\hline 0.50 & 5 & - & 38 \\
\hline 0.50 & 10 & 10 & 28 \\
\hline 0.50 & 15 & 11 & 17 \\
\hline 0.20 & 5 & - & $>43$ \\
\hline
\end{tabular}

Fig. II.

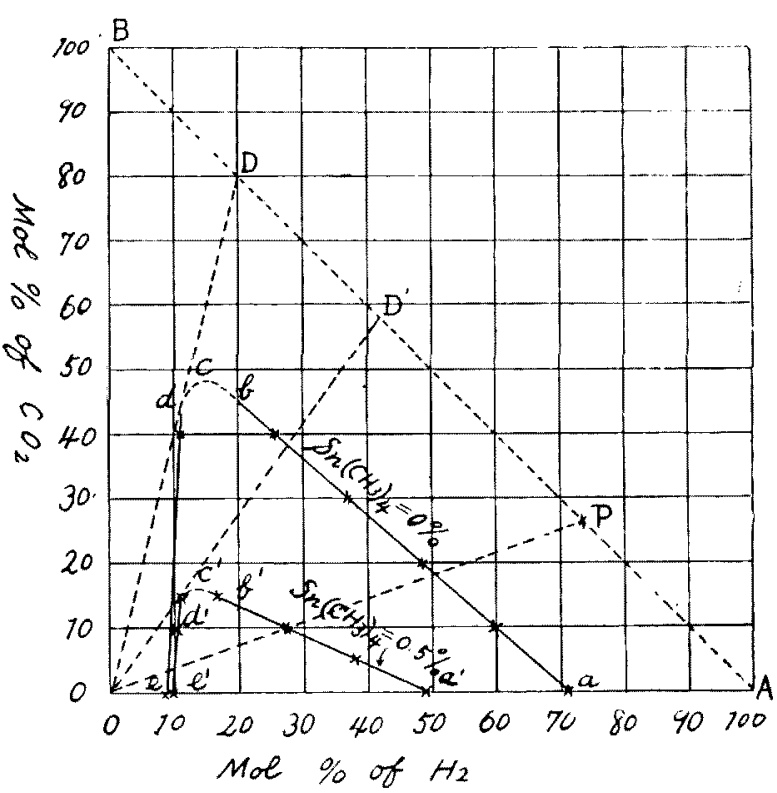

Figs. I and II show the above results graphically, the areas abcde in the both Figures representing the compositions of those mixtures which propagate flame downwards and which contain no tetramethyl tin. By the addition of $0.50 \%$ of tetramethyl tin, those areas are reduced to $a^{\prime} b^{\prime} c^{\prime} d^{\prime} e^{\prime}$, the latter being far smaller than the former. This reduction in areas is due to the rising of the theoretical flame propagation temperature of hydrogen, caused by the tin compound added.

Now the composition of any mixture of hydrogen and nitrogen or that of any mixture of hydrogen and carbon dioxide can be represented by a point $P$ on the straight line $A B$ in Fig. I or II respectively, while that of any mixture of $P$ with air by a point on the 
straight line $O P$. Therefore if $P$ is between $A$ and $D$, one can make such mixture by mixing $P$ with air that would propagate the flame downwards, the point $D$ being the intersecting point of $A B$ with the tangential line $O D$ to the curve abcde. In the presence of $0.50 \%$ of tetramethyl tin, $P$ must be between $A$ and $D^{\prime}$, in order that mixture of $P$ and air can propagate the flame downwards, the line $O D^{\prime}$ being tangent to the curve $a^{\prime} b^{\prime} c^{\prime} d^{\prime} e^{\prime}$. In other words, by the addition of $0.50 \%$ of tetramethyl tin, a considerable increase (from about $15 \%$ up to about $30 \%$ in the case of Fig. I; and from about 20\% up to about $40 \%$ in the case of Fig. II) can be made in the maximum permissible concentration of hydrogen in that mixture of hydrogen with nitrogen (or with carbon dioxide) which would not propagate flame downwards even if it is mixed with air in the best proportion.

These are, however, true only for the downward propagation of flame. If the upward propagation comes into account to any extent, the above description does not hold strictly. In this respect the following experimental results obtained by the authors will be interesting. Table $\mathrm{V}$ shows the effect of explosion-suppressors on the minimum concentration of hydrogen in hydrogen-nitrogen mixtures required to keep the flame alight on a burner, through which the gaseous mixtures were allowed to pass into the air. The burner consisted of an iron tube of $2 \mathrm{~mm}$. in internal diameter.

Table VI shows the same, except that hydrogen-carbon dioxide mixtures are used instead of hydrogen-nitrogen mixtures.

Table V. Effect of explosion-suppressors on the minimum concentration of hydrogen

in hydrogen-nitrogen mixtures required to keep the flame alight on a burner.

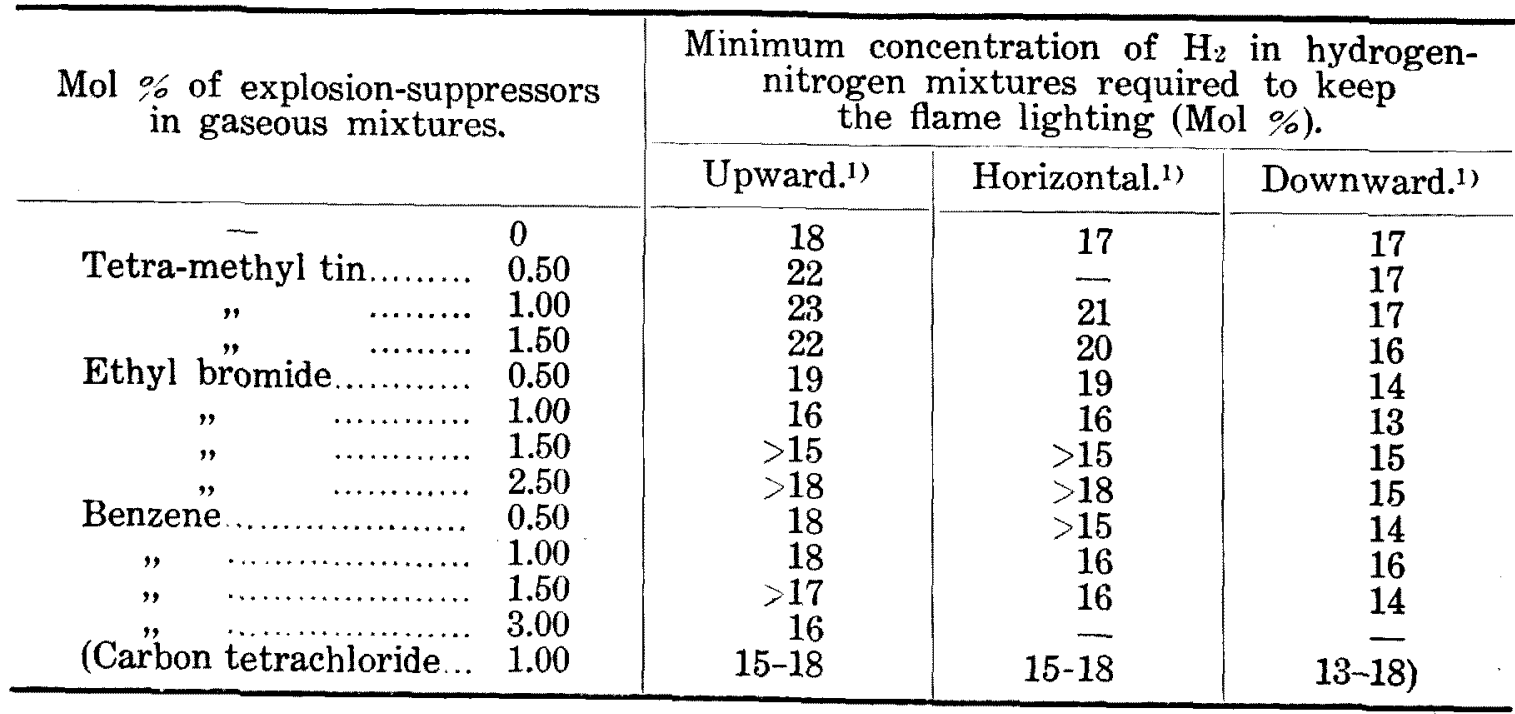

1) These are the direction of the flow of gaseous mixtures from the burner. 
Table VI. Effect of tetramethyl tin on the minimum concentration of hydrogen in hydrogen-carbon dioxide mixtures required to keep the flame alight on a burner.

\begin{tabular}{|c|c|c|c|}
\hline \multirow{2}{*}{$\begin{array}{l}\text { Mol of of } \\
\left.\text { Sn(CH }_{3}\right)_{4} \text { in } \\
\text { gaseous } \\
\text { mixtures. }\end{array}$} & \multicolumn{3}{|c|}{$\begin{array}{l}\text { Minimum concentration of } \mathrm{H}_{2} \text { in hydrogen- } \\
\text { carbon dioxide mixtures required to } \\
\text { keep the flame lighting. }\end{array}$} \\
\hline & Upward. & Horizontal. & Downward. \\
\hline 0 & 22 & 22 & 19 \\
\hline 0.50 & 24 & 24 & 20 \\
\hline 1.00 & $>22$ & $>22$ & 21 \\
\hline 1.50 & $>24$ & 23 & 23 \\
\hline 2.50 & $>23$ & 22 & 22 \\
\hline
\end{tabular}

Fig. III gives the curves showing the results for the upward flow listed in Table V. Other results give the similar curves. It can be seen that if the small amount of tetramethyl tin (or that of other explosion-suppressor) is added to the hydrogen-nitrogen mixtures or to the hydrogen-carbon dioxide mixtures, the minimum concentration of hydrogen required to enable the mixtures to selfsustain the flame on a burner generally increases at first a little and then decreases, as one proceeds to the large concentration Fig. III. of the added substances. The

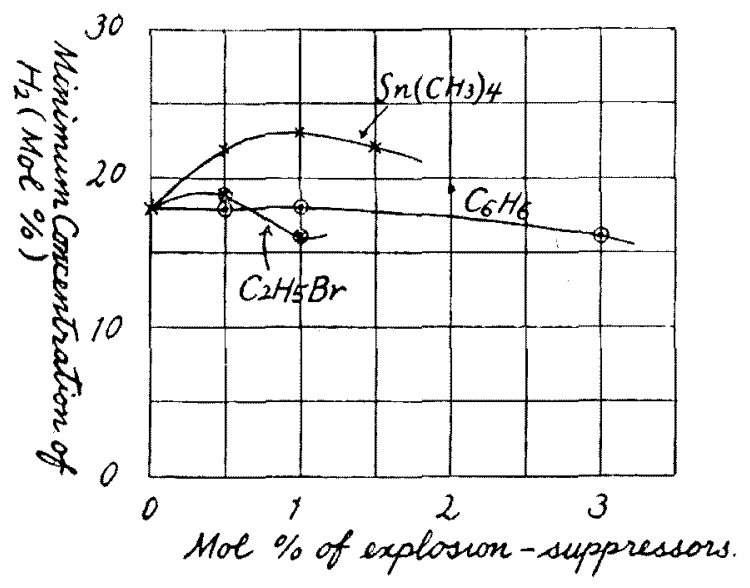
first increase is to be ascribed to the rising of the theoretical flame propagation temperature of hydrogen caused by the addition of the explosion-suppressors, while the decrease in the minimum concentration is due to the heat of combustion of the added substances. 